\title{
Water and The Middle East Peace Process
}

\author{
By Nicole Waintraub
}

\section{ABstract}

In the Israeli-Palestinian peace process, the issue of water is presented as an issue for technical cooperation that must be attended to in negotiations independent of other aspects of final settlement. To sustain such a framework for negotiation, each party must come to the table supported by domestic discourse, which is compatible with the envisioned settlement. While the Israeli public is primed to accept a settlement on water characterized by joint or cooperative management, the Palestinian public is not prepared to recognize such an agreement. Due to factors emanating from territorial dispossession and experience with the peace process, the discourse on the Palestinian side, however, has not undergone such a shift. In contrast, the Palestinians operate parallel discourses: one on the international stage of cooperation and another on the domestic stage of dispossession and rights-driven calls for "water sovereignty". As it stands, this dual discourse renders unlikely the possibility of a negotiated settlement over a scarce resource. Based on this analysis, it may be necessary for third parties engaged in the Israeli-Palestinian peace process to develop strategies to address divergent discourse and accommodate Palestinian concerns into the negotiating framework.

\section{INTRODUCTION}

The Middle East is often cited as an example of the challenges facing water-scarce regions around the world. Perhaps for this reason, the term "water wars"-the outbreak of war in order to conquer territory for its water endowments-was formulated by way of prognostications for the region. Though the Middle East is referred to as the world's most water-challenged region, the dreaded "water wars" have not come to pass. ${ }^{1}$ Instead, conflict over water in the region has tended more toward cooperative management, shared use and the exploration of commercial alternatives. ${ }^{2}$ This is the envisioned outcome in the Israeli-Palestinian conflict. This paper undertakes a study of Israeli and Palestinian domestic discourses on water and the impact of these on the prospects of the peace process. 
Domestic discourse has a significant role to play in the negotiations of the peace process as it reflects, to a certain extent, the range of outcomes that will be endorsed or consented to by the public. To be sure, it is not necessary that discourse directly support a negotiated agreement; however, there must be an appreciable level of compatibility between the two in order for the negotiated outcome to be viable and salable in terms that resonate with the public. It will be shown here that while the Israeli public is primed to accept a settlement on water characterized by joint or cooperative management, the Palestinian public is not prepared to recognize such an agreement. This is demonstrated through an overview of shifts in discourse between the 1967 Six Day War and the Oslo Process in the 1990s.

\section{The Political Symbolism Of Water}

For the Israelis, water imbues political symbolism due to its importance in the founding of the State of Israel. Rather than basing national development on geopolitical considerations, the development of the State of Israel was founded on "socialist conceptions of human and societal renewal." ${ }^{3}$ Agricultural work was seen by many as key to this form of development. The commitment to the agrarian ideal in Zionist ideology established water access as crucial to the realization of national goals. Securing access to water was fundamental and strongly linked not only to agricultural development, in particular, but more broadly to the process of rural settlement. ${ }^{4}$ As Israel expanded, a shift in discourse took place. Out of the ideological view of water grew what is referred to as 'Israeli hydrostrategic discourse'. 'Hydrostrategy' is a term used to describe the strategic thinking of a political actor, and the degree to which the location and availability of water influences this thinking. ${ }^{5}$ Whereas Zionist ideology emphasized the instrumental importance of water for redemption and a return to the land, the shift to hydrostrategic discourse added, to a certain degree, a geopolitical and military dimension to the securing of water access. The existential importance of water is, however, consistent across the shifting discourse.

The manifestation of the shift in discourse to hydrostrategic thought is most apparent in the late 1960s. In December 1968, following the 1967 Six Day War, Israel issued Military Order No. 291 in the West Bank, suspending Jordanian law with regard to private water ownership and declaring all water as property of the state. ${ }^{6}$ 
During this time, Israel's water policy in the territories revolved around two core elements: the prohibition of drilling, deepening, or repairing wells without a permit granted by the state, and the metering of wells in order to monitor and enforce water quotas for Palestinian water consumption. In the meantime, Jewish settlements in the territories expanded and wells were dug in an expedited manner. ${ }^{7}$ Given that portions of the acquired territory, especially in the West Bank, held-and continue to hold-valuable reserves of fresh water, the prospect of giving up this territory came to be seen as a threat to Israel's control over water in the region and, by extension, the security of the state in its totality. Local officials, by way of public pronouncements, were able to disseminate this position to the public. ${ }^{8}$ The resulting proponents of the hydrostrategic discourse were not only opposed to making concessions to the Palestinians, many were also opposed to engaging in any negotiations over water access. ${ }^{9}$

For the Palestinians, the political symbolism of water is bound up with the constellation of issues relating to territorial dispossession. The discourse that developed over water, therefore, was structured around the rights that are tied to land. As a result of the events outlined above, the claims to water rights amongst Palestinians grew sharply after the war in $1967 .{ }^{10}$ From the Palestinian rights discourse, the following set of priorities was expressed when addressing the issue of water access: of foremost importance is the attainment of water rights. The attainment of water rights implies full and unquestioned access to, and control over, the water that falls within territorial boundaries, as well as full control over critical water infrastructure. ${ }^{11}$ Only once this has been accomplished can attention then be directed toward developing new water sources and addressing other issues of water scarcity. ${ }^{12}$

In its most codified form, the Palestinian water rights discourse is organized around the following principles of international water law:

6. Natural attributes of the water source,

7. Prior use,

8. Alternative resources and comparative cost, and

9. Avoidance of appreciable harm.

According to this framework, many Palestinians believed that any division of water in the West Bank would disproportionately favour the Palestinian side because:

1. The waters of the West Bank's Western and Northern aquifers fall wholly within Palestinian territory; 
2. Israeli claims to the water based on "prior or existing use" would be voided as they are based on Israel's unilateral declarations and cannot be held legally binding without the consent of the country's co-riparian;

3. The most readily available alternative in the region is desalinated brackish or seawater. The cost of accessing this alternative process is comparatively less expensive for Israel and prohibitively expensive for Palestinians; and

4. Israel's denial of water to the Palestinians has caused appreciable harm that can only be rectified through re-allocation in favour of the Palestinians. ${ }^{13}$

To be sure, the application of international water law is not without its difficulties; often individual principles of international water law conflict with one another, and can be used selectively to build a case for water rights. ${ }^{14}$ This form of legal relativism notwithstanding, the concepts of inalienable rights and justice are laced throughout the political discourse of water for the Palestinians. While the discourse of rights is not necessarily incompatible with negotiation, it does set a "red line" for the Palestinian side that negates the Israeli claim to any water in the West Bank through a negotiated settlement.

\section{The Exceptionality Of Water And The Primacy Of Cooperation}

The pattern of water scarcity in the Middle East, in general, and Israel and the Palestinian territories, in particular, has long been presented as a challenge to strategic stability and an impediment to all tracks of the peace process. As it stands, economic development and population growth are expected to further increase the strains on existing water sources, aggravating existing tension. ${ }^{15}$ Far from breeding violent conflict over shared sources, however, studies have shown that water scarcity is more likely to bring about cooperation and coexistence. This is so because scarcity creates interdependencies, or mutual vulnerabilities, to which technical and cooperative solutions offer jointly beneficial avenues. ${ }^{16}$ Furthermore, some scholars have suggested that engaging on matters of disputed water allocation and control can improve overall conflicting relations between parties. ${ }^{17}$ While this finding is based on case studies of conflict along international waterways, many challenge it on the basis of its optimism. ${ }^{18}$ Nevertheless, the belief that the option of a negotiated settlement over the waters of the West Bank is possible has driven a track of the Israeli-Palestinian peace process in a specific direction: the direction of technical cooperation. 
Technical cooperation over water can take many forms. In the case of the IsraeliPalestinian conflict and peace process, technical cooperation has been advocated in the form of joint or cooperative water management: joint development and oversight of infrastructure, cooperation on scientific study of water in the area, and joint targeting and monitoring of water consumption. ${ }^{19}$ This section reviews the treatment of water in the peace process-as an item for cooperative engagement-over the 1990 s and into the $21^{\text {st }}$ century.

It can be argued that the technical and cooperative framing of the Israeli-Palestinian water issue truly took root with the pronouncements of the September 1993 Declaration of Principles on Interim Self-Government Arrangements (the Declaration of Principles) by the State of Israel and the Palestinian Liberation Organization (PLO). The Declaration of Principles established the foundation for a five-year framework for the peace process, including the formation of a Palestinian self-government arrangement, with a view to an eventual final settlement. Article XI of the Declaration of Principles, entitled, "Israeli-Palestinian Cooperation in Economic Fields," describes the mutual benefit to be gained through cooperation; further, Article XI calls for the establishment of a committee to oversee programs on areas particularly suited to cooperation. The first area outlined in the corresponding Annex III is water. Herein the Declaration calls for the founding of a Water Development Program —an expert group tasked with identifying viable modes of cooperation over water resources to be implemented during and beyond the interim period.

The cooperation over water that is addressed under Article $\mathrm{XI}$ is worthy of special attention. Other fields of Israeli-Palestinian economic cooperation identified under Article XI include: electricity, energy, finance, transport, communication, trade, industrial development, labour relations, and human resources. Annex III describes each of these fields in terms of its economic or industrial significance, except for water. While water is indeed a natural resource with implications for a country's economy, its categorization as an economic issue is contestable. The fact that water is necessary for the sustainment of human life-that its value in this regard cannot be priced, nor can it be reasonably substituted-sets it apart from other economic resources. ${ }^{20}$ Access to water is vital to the survival of either party to the conflict, yet the security dynamic often attributed to water is not acknowledged in the Declaration of Principles. Instead, the issue of water access is framed as water management; it is addressed under the same rubric of economic matters and categorized as an opportunity for cooperation. 
The principle of cooperation over water was further strengthened in the September 1995 Israeli-Palestinian Interim Agreement on the West Bank and the Gaza Strip (the Interim Agreement). This agreement called for the creation of a Joint Water Committee to manage the joint water resources and enforce agreed upon water policies based on management standards for such activities as drilling for wells. The Interim Agreement also called for an increase in the amount of water made available for use by the Palestinians-an acknowledgment that Palestinians were being insufficiently supplied with water. Israel was therefore responsible for increasing the Palestinian allocation of water by twenty-eight million cubic metres. The development of water resource availability for either side was encouraged as an initiative to be funded through international channels.

International funding channels played a key role in shaping the way in which water issues are framed in the peace process. The United States Agency for International Development (USAID) announced that the water sector constitutes a strategic investment area and an "ideal sector for peace-making" following the issuing of the Interim Agreement and in support of cooperation projects. In general, the international donor community followed suit, earmarking over ten percent of all Palestinian aid money between 1993 and 2000 to cooperative water initiatives. ${ }^{21}$ It is important to note that the delivery of aid to the Palestinian territories was (and continues to be) subject to a great deal of criticism. Due to institutional obstacles on the part of the donor community and bureaucratic inefficiency on the Palestinian side, the flow of aid to the region did not meet the immediate needs to which it was meant to respond. ${ }^{22}$

The water accords achieved at Taba are considered by some to be amongst the most significant outcomes of the Oslo Process. ${ }^{23}$ While the recognition of the need to increase the allocation of water to the Palestinians figured prominently in this assessment, the focus in terms of achievement is the founding of the Joint Water Committee (JWC). The JWC is a body composed of the Israel Water Commission and the Palestinian Water Authority, each with equal representation and veto power; it constitutes the primary mechanism for cooperation and coordination over water. ${ }^{24}$ Specific activities carried out by the JWC include: licensing of new wells and other such water installations, monitoring and regulating extraction quotas from water sources, and planning and overseeing the implementation of construction projects for new water and sewage systems. JWC compliance duties are carried out by the Joint Supervision and Enforcement Teams, also with equal Israeli and Palestinian representation. 
The value attributed to cooperation and the exceptional nature of water in the IsraeliPalestinian conflict is further underlined by the special status it was allocated through the IsraelPalestinian JWC's January 2001 Joint Declaration for Keeping the Water Infrastructure out of the Cycle of Violence (the Joint Declaration). In this declaration, both sides of the joint committee expressed their dedication to ensuring the provision of water services despite the rising incidence of violence at the time. They implored that their respective communities not damage critical water infrastructure and drew particular attention to the fact that Israeli and Palestinian water infrastructure is intertwined. Damage to pipelines, pumping stations and drilling equipment, it was noted, will compromise services to both sides. The language employed in the Joint Declaration is well aligned with the cooperative discourse on water management. To be sure, the public did not observe the principles advanced in the Joint Declaration. Mark Zeitoun provides a detailed description of the attacks on water infrastructure carried out following the declaration by the joint committee. ${ }^{25}$ Nevertheless, the fact that such a supplication was made by a joint institution speaks to the salience of cooperation in the peace process.

The framing of water issues described in this section is both aligned with and symptomatic of the belief that without conceptual intervention, water issues have the potential to derail the peace process. Beyond the need to frame water access considerations in terms of technical cooperation, there also seems to be a belief that extracting and isolating water, as an item for negotiation, is vital to the overall Israeli-Palestinian peace process. This outlook was not exclusive to the effort in the peace process during the 1990s. For example, at the Camp David Summit in 2000, water-related issues were discussed remotely from other central final status issues, in Emmetsburg, lowa. Practitioners described that introducing water-related issues to the central negotiations risks "poisoning" the entire effort. ${ }^{26}$ The risk referred to here seems to emanate from the political symbolism of water that is apt to arise when the issue is analyzed alongside questions of territorial division and control in a final status arrangement. This is especially the case with regard to the Palestinian claim to full sovereign rights over territorial water and the Northern and Western aquifers of the West Bank. The framing of water issues as an isolated matter for technical cooperation is a signal of the strategic approach to potentially politically- and symbolically-laden issues in the peace process. 


\section{Development Of The Cooperation Discourse}

The emphasis on cooperation over water in the peace process is, in many ways, far removed from and incompatible with the respective political discourses previously described for the Israelis and the Palestinians. The process of developing a cooperation discourse in support of the tenets of the peace process has been dramatically different for each side. For the Israelis, it seems that the hydrostrategic discourse has been phased out of the public mentality due to changes in Israel's social setting and the accompanying changes in the perception of water issues. Eran Feitelson (2002) describes this transition in Israel as being a result of the confluence of the growing institutionalization of water management, the decline in salience of the agricultural sector, and the growing ecological discourse over water. According to Feitelson, over the course of the 1960s and 1970s, water was decreasingly the subject of public pronouncements and ideological discussion and increasingly the domain of an insular professional community, populated by practitioners and scientists. Furthermore, as agricultural production in Israel shifted from self-sufficiency to export, and food security was ensured through grain import and storage, agriculture was de-coupled from state survival. ${ }^{27}$ Finally, the rise of an ecologically oriented technocracy within Israel's city planning sector added to the shift in thinking on water. ${ }^{28}$

To be sure, the transition in discourse from hydrostrategic to cooperative did not take root in full across the country automatically. There remain some who view water through a strategic lens. At best, the social position on water in Israel can be seen as fragmented. ${ }^{29}$ Nevertheless, the change in mentality that did occur allowed for the emergence, in time with Oslo, of a broad group of Israelis that was willing to acknowledge legitimate Palestinian domestic water needs and advance a discourse of technical cooperation. Though this group did not acknowledge full Palestinian rights to water-especially with regard to economic and agricultural developmentits members did recognize the need to rectify past disproportionate water allocations through cooperative measures. ${ }^{30}$ When framed properly, it seems that water issues in the context of the Israeli-Palestinian dispute could gain consensus across ideological lines in Israel. Moreover, water could be addressed through the peace process, provided that it avoided the rights discourse. $^{31}$ 
Compared to the case of Israel, the transition in discourse for the Palestinians was far less gradual and was not driven by internal developments. Whereas the shift in discourse on the Israeli side was part of a decades-long domestic process of decoupling water from political ideology and strategic analysis, the rights-based discourse amongst Palestinians did not dissipate gradually. Instead, it was displaced abruptly, at the official level, by the discourse of cooperation in time with the Oslo Process, following the Interim Agreement. In this regard, the official discourse of cooperation was delivered primarily through the Palestinian Water Authority (PWA) — the body established by the Interim Agreement to represent the Palestinian people on the JWC. The PWA committed to advancing the principles of cooperative water and wastewater management. As a part of its public endorsement of cooperative water management, and in the face of extensive damage to critical water infrastructure on the Palestinian side, the PWA continued to publicly endorse cooperation with its Israeli counterpart despite the outbreak of the Al Aqsa Intifada. ${ }^{32}$ As already mentioned, it was at this point that the PWA issued, along with the Israeli side, the Joint Declaration.

It has been argued that the official discourse of cooperation on the Palestinian side is advanced as a "parallel sanctioned discourse", meaning that it is employed alongside another distinct discourse depending on the political environment. ${ }^{33}$ In the context of the peace process and for the sake of engaging the international donor community, Palestinian officials advocate cooperative water management. In contrast, when engaging the domestic audience, Palestinian officials shift discourses, emphasizing instead the injustice of Israel's policies and calling for full sovereignty over water-the rights-based discourse. Even representatives of the PWA have made unofficial declarations of resentment of Israeli policy. ${ }^{34}$ This approach has been labeled as pragmatic by some and politically opportunistic by others. Regardless of the characterization, the practice indicates that the discourse of cooperation does not coincide with consolidated domestic support for the principle of cooperation in the peace process with a view to a final status agreement. The prospect of joint or cooperative management as a part of a final settlement is not supported by discourse on the Palestinian side.

\section{The Causes And Implications Of Unconsolidated Cooperation Discourse}

To be sure, the discourse of cooperation was not universally supported on the Israeli side; however, alternate discourses were either conceptually compatible with the principle of technical cooperation or marginal in the public domain. 
The approach adopted in the peace process through the 1990s was able to resonate with the public and generate support.

On the Palestinian side, the parallel discourses that were advanced ran counter to one another. The discourse of cooperation was, in general, not disseminated domestically; rather, it was reserved for international relations. Upholding the inalienable principle of territorial rights, in general, and water rights, in particular, was a fundamental component of the Palestinian position. In this regard, political symbolism and water were inextricable.

Further to there being resistance to the de-politicizing of water over the course of the 1990s, there was also distinct contempt for the notion of cooperation. In the experience of the Palestinians, "cooperation" in practice did not yield significant improvements. To begin, the peace process' division of water access was unequal. According to the terms of the Interim Agreement, Israel and its West Bank settlers were able to consume eighty-seven percent of the total water yield of the territory's two trans-boundary aquifers. While Israeli consumption of water was relatively unchecked, Palestinian consumption was closely monitored and limited. ${ }^{35}$ Furthermore, the administration of water at the local level seemed to marginalize the PWA and the needs of Palestinians. Applications for procedures as straight forward as repair work to Palestinian water infrastructure were often drawn-out over months or years despite the PWA equal stature on the JWC. ${ }^{36}$ Such realities on the ground further bolstered the call for total and complete sovereignty over Palestinian territory and its resources. From the perspective of public officials, it also rendered unfeasible the propagation of cooperation rhetoric amongst the domestic population.

That the discourse of cooperation is conspicuously unconsolidated on the Palestinian side has implications for the peace process and prospects for final status negotiations over water. While the parallel discourses were somewhat tenable through the Oslo Process, final status talks would bring the incompatible principles of cooperation and rights under direct scrutiny on the international and domestic stages.

Though there has been some recent support for the advancing of needs-based as opposed to rights-based claims to water on the Palestinian side, the parallel discourses of cooperation and water-sovereignty have not given way. ${ }^{37}$ In a process aimed at dividing territory, the win-sets available to Palestinian negotiators in final status talks would be significantly more constrained, if not non-negotiable, than those of their Israeli counterparts. 


\section{Conclusion}

In a water-scarce region such as the Middle East, water access is bound to be fraught with political symbolism and a sense of existential threat. By removing the political symbolism carried by the issue of water access, the cooperation framing and its supportive discourse broadens the range of available win-sets in a negotiating framework. It does so by removing the perception of a zero-sum environment by the parties' respective domestic constituencies. For the Israeli side it could be argued that, by the 1990s, the domestic constituency was primed and had undergone the necessary developments to be able to embrace a solution to the water issue, so long as it occurs through cooperative means. For the Palestinians, in contrast, the same developments have not taken place. Rather than adopting a cooperative discourse domestically_or a needs-based discourse, which is more compatible with the cooperative agreements envisioned-Palestinian officials continue to advanced parallel sanctioned discourses. The Palestinian constituency is, therefore, still primed to view water issues through a rights-based, zero-sum lens. As it stands, it is unlikely that the two parties can come to final status negotiations equally committed to implementing cooperative measures over the region's most scarce resource. It is possible, however, that improvements can be made if third parties active in the peace process develop initiatives specifically intended to align public discourse and political communications, with the goals of final settlement. This would likely involve an acknowledgment of historic grievance over water access as well as special attention to the potential for double standards in cooperative management institutions.

\section{About the Author}

Nicole Waintraub recently completed her M.A. in Public and International Affairs at the University of Ottawa. Her major research paper on the relevance of Track II Diplomacy for regional security, arms control and non-proliferation in the Middle East was granted The Simons Foundation and DFAIT International Security Research Outreach Programme's Graduate Research Award. Nicole hopes to continue her studies at the doctoral level.

\section{ENDNOTES}

1 John Anthony Allan, "Hydro-Peace in the Middle East: Why no Water Wars?: A Case Study of the Jordan River Basin," SAIS Review 22:2 (2002): 255-272; Aaron T. Wolf, "Conflict and cooperation along international waterways," Water Policy, 1 (1998): $251-265$. 
2 Allan, 2002.

${ }^{3}$ Alwyn Rouyer, Turning Water into Politics: The Water Issue in the Palestinian-Israeli Conflict (New York: Palgrave, 2002$) 82$.

${ }^{4}$ Eran Feitelson, "Implications of Shifts in the Israeli Water Discourse for Israeli-Palestinian Water Negotiations," Political Geography, 21 (2002): 300

${ }^{5}$ Aarib T. Wolf, Hydropolitics Along the Jordan River, (New York: United Nations University Press, 1995) 73.

${ }^{6}$ Rouyer, 2002: 47.

7 Rouyer, 2002: 48

${ }^{8}$ Feitelson, 2002: 75-76

${ }^{9}$ Mark Zeitoun, Power and Water in the Middle East: The Hidden Politics of the Palestinian-Israeli Water Conflict (London: I.B. Tauris, 2008) 75.

${ }^{10}$ Zeitoun, 2008: 80

11 Jan Selby, Water, Power and Politics in the Middle East: The Other Israeli-Palestinian Conflict (London: I.B. Tauris, 2003$) 30$.

12 Zeitoun, 2008.

${ }^{13}$ Sharif Elmusa, "Dividing Water Resources According to International Water Law: The Case of the Palestinian-Israeli Waters," Natural Resources Journals, 35 (1995) 235-240.

${ }^{14}$ Aaron T. Wolf, "Criteria for Equitable Allocations: The Heart of International Water Conflict," Natural Resources Forum, 23:1 (1999a) 3-30.

${ }^{15}$ Rouyer, 2002: 31

${ }^{16}$ Mustapha Dolatyar and Tim Gray, "The Politics of Water Scarcity in the Middle East," Environmental Politics, 9:3 (2000) 67; Aaron T. Wolf, "Water Wars and Water Reality: Conflict and Cooperation Along International Waterways," in Steve C. Lonergan (ED.), Environmental Change, Adaptation, and Security (Netherlands: Kluwer Academic Publications, 1999b).

${ }^{17}$ David K. Hambright, F. Jamil Ragep and Joseph Ginat, Water in the Middle East: Cooperation and Technological Solutions in the Jordan Valley (Norman, OK: University of Oklahoma Press, 2006) xii.

${ }^{18}$ Selby, 2003.

${ }^{19}$ Hambright, et al, 36 .

${ }^{20}$ Myriam Lowi, "Water and Conflict in the Middle East and South Asia: Are Environmental Issues and Security Issues Linked?" The Journal of Environmental Development, 8 (1999) 377; Jon Barnett, "Destabilizing the Environment-Conflict Thesis," Review of International Studies, 26 (2000) 273.

${ }^{21}$ Selby, 2003: 5. The dominance of support for projects characterized as "cooperative" is the subject of some controversy. A World Bank report entitled, "Thirty-six Months of Intifada," described donor fatigue on the part of organizations attempting to support water initiatives that were not aligned with the cooperation discourse. These organizations met with difficulty in implementing their initiatives due to lack of collaboration on the ground. As these organizations were subject to increased pressure from their head offices to "deliver", there was an increasing alignment with the status quo.

${ }^{22}$ Rex Brynen, "Buying Peace? A Critical Assessment of International Aid to the West Bank and Gaza," Journal of Palestine Studies, 25:3 (1996) 79-92.

${ }^{23}$ Alwyn Rouyer, "The Water Accords of Oslo II: Averting a Looming Disaster," Middle East Policy, 7:1 (1999) 114. It is important to note that Interim Agreement does acknowledge the "water rights" in the West Bank; however, this point lacks elaboration and a further description of what constitutes "rights" in this case is left for final status negotiations. This aberration in the general approach to water issues in the peace process is attributed by some to confusion amongst negotiators over acceptable language.

${ }^{24}$ Zeitoun, 2008: 99.

${ }^{25}$ Zeitoun, 2008: 88-91

${ }^{26}$ Jonathan Lautze, Meredith Reeves, Rosaura Vega and Paul Kirshen, "Water Allocation, Climate Change and Sustainable Peace - The Israeli Proposal," Water International, 30:2 (2005) 197-209.

${ }^{27}$ Sharif Elmusa, Water Conflict: Economics, Politics, Law and Palestinian-Israeli Water Sources (Washington, DC: Institute for Palestine Studies, 1997) 279

${ }^{28}$ Feitelson, 2002: 304.

${ }^{29}$ Feitelson, 2002: 306.

${ }^{30}$ Zeitoun, 2008: 77-78.

${ }^{31}$ Eran Feitelson, "Political Economy of Groundwater Exploration: The Israeli Case," Water Resources Development, 21:3 (2005) 418; Arnon Soffer, "Mapping Special Interest Groups in Israel's Water Policy" (Begin-Sadat Center for Strategic Studies, Bar Ilan University, Department of Political Science, 2002).

${ }^{32}$ Zeitoun, 2008: 91

${ }^{33}$ Julie Trottier, "Water Wars: The Rise of a Hegemonic Concept - Exploring the Making of the Water War and Water Peace Belief within the Israeli-Palestinian Conflict." Paper prepared for the Green Cross International project From Potential Conflict to Co-operation Potential. (Geneva, Switzerland, 2003). 
${ }^{34}$ Allouche, cited in Zeitoun, 2008: 79.

${ }^{35}$ Selby, 2003: 105.

${ }^{36}$ Zeitoun, 2008: 99-102.

${ }^{37}$ David J.H. Phillips, Shaddad Attili, Stephen McCaffrey, and John S. Murray, "Factors Relating to the Equitable Distribution of Water in Israel and Palestine," paper presented at UNESCO's $2^{\text {nd }}$ Israeli-Palestinian International Conference on Water for Life in the Middle East, 2004: 3. 
